\title{
Article \\ The Effect of Ripening Stages on the Accumulation of Carotenoids, Polyphenols and Vitamin C in Rosehip Species/Cultivars
}

\author{
Brigita Medveckienè $^{1, *}$, Jurgita Kulaitienè ${ }^{1}$, Dovilè Levickienè ${ }^{1}$ and Ewelina Hallmann $^{2}$ (D) \\ 1 Institute of Agriculture and Food Sciences, Vytautas Magnus University Agriculture Academy, \\ Donelaičio Str. 58, 44248 Kaunas, Lithuania; jurgita.kulaitiene@vdu.lt (J.K.); dovile.levickiene@vdu.lt (D.L.) \\ 2 Department of Functional and Organic Food, Institute of Human Nutrition Sciences, \\ Warsaw University of Life Sciences, Nowoursynowska 159c, 02-776 Warsaw, Poland; \\ ewelina_hallmann@sggw.pl \\ * Correspondence: brigita.medveckiene@vdu.lt; Tel.: +370-6258-0444
}

check for updates

Citation: Medveckienė, B.; Kulaitienè, J.; Levickienė, D.; Hallmann, E. The Effect of

Ripening Stages on the

Accumulation of Carotenoids, Polyphenols and Vitamin C in Rosehip Species/Cultivars. Appl. Sci. 2021, 11, 6761. https://doi.org/ 10.3390/app11156761

Academic Editor: Encarna Aguayo

Received: 23 June 2021

Accepted: 21 July 2021

Published: 23 July 2021

Publisher's Note: MDPI stays neutral with regard to jurisdictional claims in published maps and institutional affiliations.

Copyright: (c) 2021 by the authors. Licensee MDPI, Basel, Switzerland. This article is an open access article distributed under the terms and conditions of the Creative Commons Attribution (CC BY) license (https:/ / creativecommons.org/licenses/by/ $4.0 /)$.

\begin{abstract}
Our research was aimed at assessing the effect of accumulation of carotenoids, polyphenols, vitamin $C$ and ripening stage in the rosehip fruits of two species-Rosa canina, Rosa rugosa and two cultivar-Rosa rugosa 'Rubra' and Rosa rugosa 'Alba'. The amounts of carotenoids, polyphenols and vitamin $C$ were determined using the high-performance liquid chromatography (HPLC) method. The obtained results showed that the significantly highest amount $\left(107.15 \mathrm{mg} 100 \mathrm{~g}^{-1}\right)$ of total carotenoid was determined in the fruits of Rosa canina at ripening Stage V. While results indicated that significant amount of total polyphenols were established at Stages I and II in the Rosa Rugosa 'Alba' and Rosa

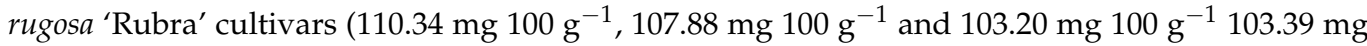
$\left.100 \mathrm{~g}^{-1}\right)$. At ripening Stage I, in the fruits of Rosa rugosa the greatest increases were established in the

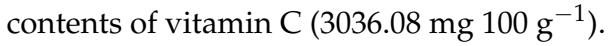

Keywords: organic; rosehip; polyphenols; carotenoids; Vitamin C

\section{Introduction}

Recent developments in the fields of health and food have encourage renewed interest in natural antioxidant compounds. A diet rich in antioxidant components has potential effects on the human health by reducing the risk of various diseases, for example cardiovascular diseases, cancers and age-related macular degeneration [1].

In an effort to find plants that produce antioxidants, of particular interest are the fruits of the rose plant (Rosa spp.), which have long been used as a raw material for medicines, vitamins, and food.

Rosehips, the fruits of rose plants (Rosa spp.) have been discovered to be rich in polyphenols (triterpene acids, flavonoids, proanthocyanidins, catechin), vitamin A, C and E, essential fatty acids, galactolipid, minerals ( $\mathrm{Ca}, \mathrm{Mg}, \mathrm{K}, \mathrm{S}, \mathrm{Si}$, Se, Mn and $\mathrm{Fe})$, among other bioactive components [2,3].

The health benefits of rosehip can be primarily attributed to their high concentration of natural antioxidants such as phenolic compounds, vitamin $C$ and carotenoids. Although rosehips had more recently attracted attention because of their potential health benefits, there was little information about the changes of antioxidants properties that occur during the maturity especially in Rosa rugosa, Rosa rugosa 'Alba', Rosa rugosa 'Rubra' species [4-6]. The extracts have been proven to possess antioxidant, anti-inflammatory, immunomodulation, anticancer, cardioprotective, antidiabetic, neuroprotective, and antimicrobial properties [2].

Rosehips are usually harvested in late summer or in autumn. The content of biologically active compounds is proved to depend on a number of factors, i.e., species/variety, 
ripening stage, and environmental growing conditions. Although the chemical composition of Rosa spp. fruits is known, but there is lack of research on how ripening stages influence the chemical composition and their antioxidant properties of the fruits. The fruits do not reach maturity simultaneously, green to red color fruits coexist in the same plant. Understanding fruit physico-chemical properties and nutritional properties is important in the design of cost-effective and efficient postharvest handling equipment, optimization of bioprocesses in functional food manufacture, and natural medicinal products. Therefore, these results are useful for determining the optimal harvest time of rosehip, when the maximum level of bioactive components, as well as rosehip are could be used in food industry and medicine as important natural agents.

It is imperative to note that there is no information in literature about cultivation of Rosa spp. in an organic system.

Understanding physicochemical properties of fruits during the ripening is important to promote the levels of bioactive compounds through the selection of cultivar/species and harvest time.

Therefore, the purpose of this research was to investigate the effect of ripening of two rosehip fruit species and two cultivars on the contents of carotenoids, polyphenols, and vitamin $C$ grown under organic management system.

\section{Materials and Methods}

\subsection{Field Experiment}

The field experiment was conducted in 2018-2019 at an organic farm in Pakruojis district, Lithuania $\left(56^{\circ} 10^{\prime} 29.0^{\prime \prime} \mathrm{N} 23^{\circ} 49^{\prime} 02 \cdot 6^{\prime \prime} \mathrm{E}\right)$.

The soil of the experimental field had the following properties: $\mathrm{pHKCl}=6.14$ $6.85 \mathrm{mg} \mathrm{kg}^{-1}$, potassium: $83.2-154.8 \mathrm{mg} \mathrm{kg}^{-1}$, phosphorus: $22.6-137.1 \mathrm{mg} \mathrm{kg}^{-1}$ total nitrogen: $2.67 \%$.

The experimental assaying was established in 10-year-old rosehip shrubs, with a planting spacing rows $4 \mathrm{~m}$ and spacing between plants $2 \mathrm{~m}$. The treatments were arranged to randomized designs with four replications. The total experimental plot was $2000 \mathrm{~m}^{2}$.

A two-factor experiment: Factor A-two rosehip species and two cultivars: Rosa rugosa (pink flowers, fruits red, spherical (tomato-shaped hips), about $2.5-3 \mathrm{~cm}$ in diameter), Rosa canina (pale pink flowers, fruits red-orange, oval, about $1.5-2 \mathrm{~cm}$ in diameter) and Rosa rugosa cv 'Rubra' (violet-purplish flowers, fruits red, spherical (tomato-shaped hips), about $2.5-3 \mathrm{~cm}$ in diameter), Rosa rugosa cv 'Alba' (pure white flowers, fruits orange-red, spherical (tomato-shaped hips) about $2.5-3 \mathrm{~cm}$ in diameter). The selected species/cultivars grow best in the climatic conditions of the Lithuania. Factor B-ripening stage (Figure 1):

Stage I-the initial stage of ripening, at least $10 \%$ of the surface color of rosehips has changed from green to yellow, pink, red; Stage II- $10-30 \%$ of the green color surface of rosehips became dark yellow, pink and red; Stage III-30-60\% of the green color surface of rosehips transformed to light orange, red or a combination thereof; Stage IV-60-90\% of the surface color of rosehips turned orange or orange-red; Stage V-the surface of the rosehips was red or orange, depending on the species/cultivar.

The weather data during experimental period in 2018 and 2019 are shown in Table 1.

During year 2018 and 2019 the climate was warmer (by 2.5 and $1.5^{\circ} \mathrm{C}$, respectively) in comparison with the standard climate normal (SCN). In 2018 and 2019 during the vegetation period, the climate was dryer (on average 86.4 and 148.9, respectively) in comparison with the SCN. Sunshine duration hours were higher on average by $264 \mathrm{~h}$, in both years during the rosehip vegetation period. 


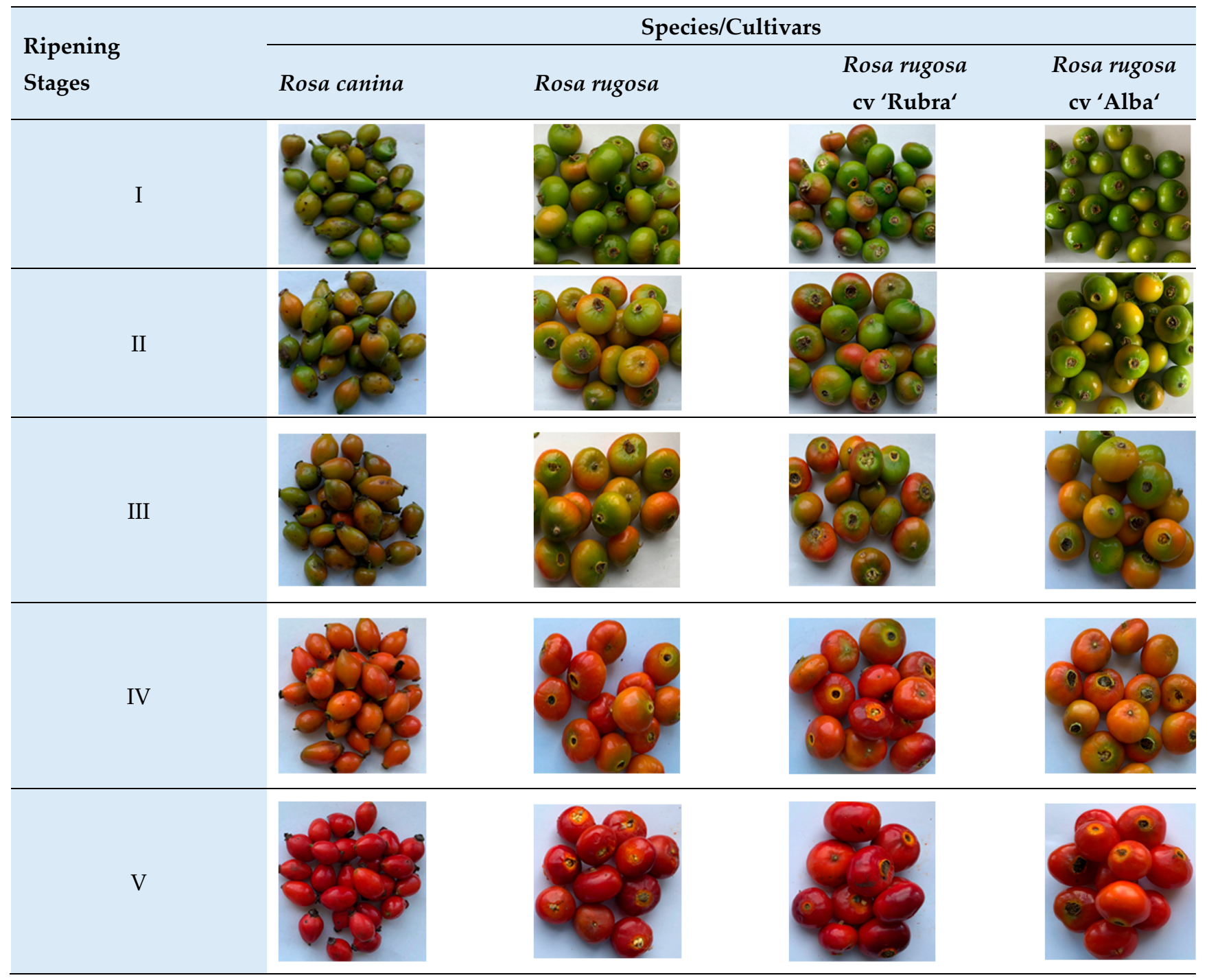

Figure 1. Fruit ripening stages of Rosa samples (photos by B. Medveckiene).

Table 1. Weather data during experimental period in 2018 and 2019.

\begin{tabular}{|c|c|c|c|c|c|c|c|}
\hline \multirow{2}{*}{ Years } & \multicolumn{7}{|c|}{ Months } \\
\hline & April & May & June & June & August & September & Average \\
\hline \multicolumn{8}{|c|}{ Air temperature, ${ }^{\circ} \mathrm{C}$} \\
\hline 2018 & 10.2 & 17.1 & 17.4 & 19.6 & 19.2 & 14.5 & 16.3 \\
\hline 2019 & 9.1 & 13.4 & 21.2 & 17.2 & 18.2 & 12.5 & 15.3 \\
\hline $\mathrm{SCN}^{*}$ & 7.0 & 12.8 & 15.7 & 18.0 & 17.1 & 12.0 & 13.8 \\
\hline \multicolumn{7}{|c|}{ Rainfall, mm } & Sum \\
\hline 2018 & 42.6 & 27.5 & 16.0 & 107.9 & 65.6 & 57.0 & 316.6 \\
\hline 2019 & 0.7 & 28.6 & 27.5 & 50.3 & 100.5 & 46.5 & 254.1 \\
\hline $\mathrm{SCN}$ & 43 & 57 & 73 & 89 & 75 & 66 & 403 \\
\hline \multicolumn{7}{|c|}{ Sunshine, $\mathrm{h}$} & Sum \\
\hline 2018 & 248 & 365 & 286 & 210 & 276 & 207 & 1592 \\
\hline 2019 & 329 & 232 & 349 & 233 & 264 & 189 & 1596 \\
\hline $\mathrm{SCN}$ & 179 & 252 & 246 & 260 & 237 & 154 & 1328 \\
\hline
\end{tabular}

* SCN—standard climate normal is the 30-year average from 1981 to 2010. Source: Šiauliai Meteorological Atation, Lithuania. 


\subsection{Preparation Samples of Rosehips}

The rosehips stem was removed after harvesting, then the fruits were cut in a half and the seeds were separated from the fruit flesh.

The rosehips flesh was frozen at $-35^{\circ} \mathrm{C}$ and lyophilised using a Freeze-Draying Plant Sublimator $3 \times 4 \times 5$ (ZIRBUS technology $\mathrm{GmbH}$, Bd Grund, Germany). The samples were lyophilised for 48 h, then were milled (Grindomix GM 200, Retsch GmbH, Haan, Germany) and stored in sealed containers at $5^{\circ} \mathrm{C}$ in the dark until further analysis.

\subsection{Carotenoids Determination}

The carotenoids content was determined by the method that was described by Hallmann [7], with some modifications. A total of $100 \mathrm{mg}$ of powdered freeze dried plant material was weighed into a plastic test tube, and then $1 \mathrm{~mL}$ of hexane (Sigma Aldrich, Warsaw, Poland) and $2 \mathrm{mg}$ of magnesium carbonate $\left(\mathrm{Mg}_{2} \mathrm{CO}_{3}\right)$ were mixed thoroughly by vortex, next incubated in an ultrasonic cold ultrasonic bath $\left(15 \mathrm{~min}\right.$ at $\left.0{ }^{\circ} \mathrm{C}\right)$. Then, centrifugation $\left(6000 \mathrm{rpm}, 10 \mathrm{~min}\right.$ at $0^{\circ} \mathrm{C}$ ) were done. Analysis parameters were as follows: mobile phases gradient flow: acetonitrile with methanol (90:10) and methanol with ethyl acetate (68:32) with a flow rate of $1 \mathrm{~mL} \mathrm{~min}^{-1}$. From the test tube, $1 \mathrm{~mL}$ supernatant was collected and was re-centrifuged at $12,000 \mathrm{rpm}$. Then, $100 \mu \mathrm{L}$ of supernatant were carefully taken and transferred into HPLC-vial, next injected for high-performance liquid chromatography (HPLC) (Shimadzu, USA Manufacturing Inc., Canby, OR, USA). To determine the carotenoids, the HPLC set-up consisted of two LC-20AD pumps, a CMB-20A system controller, an SIL-20AC auto sampler, an ultraviolet-visibleSPD-20AV detector, a CTD-20AC oven, and a Phenomenex Max 80-Å RP column $(250 \times 4.60 \mathrm{~mm})$ from Shimazu (Shim-Pol, Warsaw, Poland). The wavelength used was 450-471 nm. Lycopene (Sigma Aldrich, Warsaw, Poland) and $\beta$-carotene (Fluka, Warsaw, Poland), with purities of 99\%, were used as the external standards. Each measurement was performed in triplicate.

\subsection{Polyphenols Determination}

Polyphenols were determined using the high-performance liquid chromatography (HPLC) equipment described above and a method reported by Hallmann [7].

First, $100 \mathrm{mg}$ of freeze-dried rosehip flesh and seed sample were put into a plastic test tube, next $5 \mathrm{~mL}$ of methanol were mixed thoroughly by the vortex and incubated in an ultrasonic bath $\left(15 \mathrm{~min}\right.$ at $\left.30^{\circ} \mathrm{C}\right)$. The samples were centrifuged $\left(6000 \mathrm{rpm}, 10 \mathrm{~min}\right.$ at $\left.0{ }^{\circ} \mathrm{C}\right)$. Next, $1 \mathrm{~mL}$ of extract was obtained from the test tube and was collected and re-centrifuged at the speed of $12,000 \mathrm{rpm}$. An amount of $500 \mu \mathrm{L}$ extract was taken for the HPLC vials and analyzed. A HPLC column (Phenomenex, Fusion-80A, C-18, practical shape $4 \mu \mathrm{m}$, $250 \times 4.6 \mathrm{~mm}$, Shim-Pol, Warsaw, Poland) was used for the analysis of polyphenols. The gradient flow had two mobile phases: acetonitrile water and deionized and water for two concentrations: $55 \%$ and $10 \%$ at $\mathrm{pH} 3.00$. The time of the analysis was $38 \mathrm{~min}$, the flow rate was $1 \mathrm{~mL} \mathrm{~min}-1$, and the wavelength was $340 \mathrm{~nm}$ for flavonoids (rutin, quercetin, luteolin, astragalin, isoquercetin) and $280 \mathrm{~nm}$ for phenolic acids (gallic, chlorogenic, caffeic, ferulic, p-coumaric) compounds were identified based on Fluka and Sigma Aldrich (Warsaw, Poland) external standards with a purity of $99 \%$. All the described chemical composition analyses were performed in 3 replications.

\subsection{Vitamin C Determination}

The $100 \mathrm{mg}$ freeze-dried plant material was weighed in a plastic tube. After that, $5 \mathrm{~mL}$ of $5 \%$ meta-phosphoric acid was added. The samples were combined in a vortex before being extracted in an ultrasonic bath at $20^{\circ} \mathrm{C}$ for $10 \mathrm{~min}$ at $5500 \mathrm{~Hz}$ (PolSonic Warsaw, Poland,). Next, all samples were centrifuged with conditions: $10 \mathrm{~min}, 6000 \mathrm{rpm}, 0{ }^{\circ} \mathrm{C}$ (Centrifuge Hermle Z 300k Mirków, Poland). The supernatant was gently transferred into orange HPLC-vial and $100 \mu \mathrm{L}$ was used for analysis injection. The following analysis parameters were used: mobile phase acetic buffer $\mathrm{pH}$ 4.4. Phenomenex Hydro 80-A RP column $(250 \times 4.6 \mathrm{~mm})($ Phenomenex, Shimpol, Warsaw, Poland), analysis time $18 \mathrm{~min}$, 
detection $260 \mathrm{~nm}$. L-ASC and DHA standards were obtained from Fluka and Sigma-Aldrich (Warsaw, Poland) with 99\% purity. For each experimental combination three replicates were made. Five injections of L-ASC and DHA standards were prepared from the prepared standard solutions, and standard curves for the tested components of the vitamin $C$ were determined. Individual compounds were identified using the chromatogram and the retention time of the standards [8].

\subsection{Soil Agrochemical Analyses}

The soil agrochemical characteristic was conducted in Vytautas Magnus University Agriculture Academy Laboratory of Food Raw Materials, Agronomical and Zoo-technical Investigations. The soil samples were air-dried in open plastic boxes and having removed small stones, remains of roots and other organic plant parts, they were crushed. Homogenised soil was sieved through a $1 \mathrm{~mm}$ mesh size sieve. Soil samples were analyzed for $\mathrm{pH}_{\mathrm{KCl}}$, amounts of available phosphorus, available potassium and total nitrogen. Soil $\mathrm{pH}_{\mathrm{KCl}}$ was established by the potentiometric method in $1 \mathrm{~N} \mathrm{KCl}$ extract. Available phosphorus and potassium were extracted with ammonium-lactate according to the EgnerRiehm-Domingo method. Total nitrogen concentration $\left(\mathrm{mg} \mathrm{kg}^{-1}\right)$ was determined by the Kjeldahl method.

\subsection{Statistical Analysis}

The data on the bioactive compounds of Rosa samples were analyzed statistically using Microsoft ${ }^{\circledR}$ Excel $^{\circledR} 2016 \mathrm{MSO}$ and confirmed using the STATISTICA 10 (StatSoft, Inc., Tulsa, OK, USA, 2010) package. Since analysis of variance did not show year interaction the data are presented as two years' averages. The reliability of the results was evaluated by a two-way analysis of variance, using the ANOVA software package. The statistical significance of differences between the means was estimated by Tukey test $(p<0.05)$.

\section{Results and Discussion}

\subsection{Carotenoids}

Carotenoids are structurally and functionally a diverse group of natural pigments of the polyene type also they are very potent natural antioxidants [9]. Many of the carotenoids found in rosehips, such as zeaxanthin, lutein, lycopene, and $\beta$-carotene, have been shown to have health beneficial effect [10].

Depending on ripening stage carotenoids such as lutein, zeaxanthin, b- and a-chlorophyll, $\alpha$-carotene and $\beta$-carotene, cis- and trans-lycopene were identified and quantified in the rosehip fruit in our research. Méndez and Mosquera [10] investigated two species of rosehip (Rosa rubiginosa and Rosa eglanteria) and identified six major carotenoids- $\beta$-carotene, lycopene, rubixanthin, gazaniaxanthin, $\beta$-cryptoxanthin, and zeaxanthin, together with other minor carotenoids-violaxanthin, antheraxanthin, and $\gamma$-carotene.

The results averaged over the two experimental years revealed very large variations in content of carotenoids in the rosehips, both in terms of total amount and in composition of specific carotenoids compounds. The total amount of carotenoids was found to vary from $12.18 \mathrm{mg} 100 \mathrm{~g}^{-1}$ in Rosa rugosa 'Alba' rosehip at ripening Stage I to $107.15 \mathrm{mg}$ $100 \mathrm{~g}^{-1}$ in Rosa canina rosehip at ripening Stage V (Table 2). For all species, the lowest amounts of carotenoids were detected on the early harvesting dates which agreed with the findings published by Anderson et al. [11]. Andersson et al. [11] reported, that determined a straight correlation between weather and carotenoid contents in rosehips. Our data showed that the significantly highest amounts of total carotenoids was determined in the rosehip of Rosa canina at all ripening stages, while the lowest amount in the fruits of Rosa rugosa cv 'Alba'. In general, our results showed a significant increase of amounts of total carotenoids during the whole growing season. At the end of the experiment, at Stage V, in all investigated species/cultivars were found to contain the significantly highest amount of the total carotenoids. 
Table 2. Effects of ripening stage on the amounts of carotenoids in the rosehip fruits, $\mathrm{mg} 100 \mathrm{~g}^{-1} \mathrm{DW}$.

\begin{tabular}{|c|c|c|c|c|c|}
\hline \multirow{2}{*}{ Samples } & \multicolumn{5}{|c|}{ Ripening Stage } \\
\hline & $\mathbf{I}$ & II & III & IV & $\mathbf{V}$ \\
\hline \multicolumn{6}{|c|}{ Total carotenoids } \\
\hline Rosa canina & $20.16^{\mathrm{c}, \mathrm{d}}$ & $21.76^{\mathrm{d}}$ & $28.41^{\mathrm{e}}$ & $39.83 \mathrm{~g}$ & $107.15^{\mathrm{k}}$ \\
\hline Rosa rugosa & $13.45^{\mathrm{a}, \mathrm{b}}$ & $13.09^{a, b}$ & $15.22^{a, b}$ & $29.26^{\mathrm{f}}$ & $69.14^{\mathrm{j}}$ \\
\hline Rosa rugosa cv 'Alba' & $12.18^{a}$ & $13.57^{a, b}$ & $14.37^{\mathrm{a}, \mathrm{b}}$ & $16.81^{b, c}$ & $34.84^{\mathrm{f}}$ \\
\hline Rosa rugosa cv 'Rubra' & $19.02^{c, d}$ & $22.19^{\mathrm{d}}$ & $19.50^{c, d}$ & $28.060^{\mathrm{e}}$ & $65.19^{h}$ \\
\hline \multicolumn{6}{|c|}{ Lutein } \\
\hline Rosa canina & $5.05^{c, d, e}$ & $5.59 \mathrm{c}, \mathrm{d}, \mathrm{e}$ & $6.13^{\mathrm{d}, \mathrm{e}}$ & $7.05^{\mathrm{e}, \mathrm{f}}$ & $9.19^{\mathrm{f}, \mathrm{g}}$ \\
\hline Rosa rugosa & $5.10^{\mathrm{c}, \mathrm{d}, \mathrm{e}}$ & $4.03^{b, c, d}$ & $5.24^{\mathrm{c}, \mathrm{d}, \mathrm{e}}$ & $6.57^{\mathrm{e}}$ & $6.58^{e}$ \\
\hline Rosa rugosa cv 'Alba' & $3.72^{c, d}$ & $4.25^{\mathrm{c}, \mathrm{d}}$ & $3.96^{\mathrm{b}, \mathrm{c}, \mathrm{d}}$ & $1.93^{a, b}$ & $1.44^{\mathrm{a}}$ \\
\hline Rosa rugosa cv 'Rubra' & $4.89^{c, d, e}$ & $\begin{array}{c}5.02^{\mathrm{c}, \mathrm{d}, \mathrm{e}} \\
\text { Zeaxa }\end{array}$ & $6.51^{\mathrm{e}}$ & $9.35^{\mathrm{g}}$ & $11.26^{\mathrm{g}}$ \\
\hline Rosa canina & $0.19^{a}$ & $0.20^{\mathrm{b}}$ & $0.21^{\mathrm{c}}$ & $0.24^{\mathrm{e}}$ & $0.23^{d}$ \\
\hline Rosa rugosa & $0.19^{a}$ & $0.20^{b}$ & $0.20^{b}$ & $0.20^{b}$ & $0.20^{b}$ \\
\hline Rosa rugosa cv 'Alba' & $0.20^{b}$ & $0.20^{b}$ & $0.20^{b}$ & $0.21^{\mathrm{c}}$ & $0.21^{\mathrm{c}}$ \\
\hline Rosa rugosa cv 'Rubra' & $0.20^{b}$ & $0.20^{b}$ & $0.20^{b}$ & $0.20^{b}$ & $0.20^{b}$ \\
\hline \multicolumn{6}{|c|}{ Chlorophyll b } \\
\hline Rosa canina & $6.21^{\mathrm{h}}$ & $4.62 \mathrm{~g}$ & $3.49^{a, b, c, d, e}$ & $3.32^{\mathrm{a}, \mathrm{b}, \mathrm{c}, \mathrm{d}}$ & $3.17^{a, b}$ \\
\hline Rosa rugosa & $4.31^{\mathrm{f}, \mathrm{g}}$ & $3.86^{\mathrm{c}, \mathrm{d}, \mathrm{e}, \mathrm{f}}$ & $3.11^{\mathrm{a}, \mathrm{b}}$ & $3.03^{\mathrm{a}}$ & $3.00^{\mathrm{a}}$ \\
\hline Rosa rugosa cv 'Alba' & $3.84^{\mathrm{c}, \mathrm{d}, \mathrm{e}, \mathrm{f}}$ & $3.96^{\mathrm{d}, \mathrm{e}, \mathrm{f}, \mathrm{g}}$ & $3.32^{\mathrm{a}, \mathrm{b}, \mathrm{c}, \mathrm{d}}$ & $3.26^{a, b, c}$ & $3.05^{\mathrm{a}}$ \\
\hline \multicolumn{5}{|c|}{ Chlorophyll a } & $3.01^{\mathrm{a}}$ \\
\hline Rosa canina & $2.75^{\mathrm{c}, \mathrm{d}, \mathrm{e}}$ & $4.18^{\mathrm{e}, \mathrm{f}, \mathrm{g}}$ & $5.71^{\mathrm{g}}$ & $15.63^{j}$ & $53.11 \mathrm{~m}$ \\
\hline Rosa rugosa & $0.75^{\mathrm{a}}$ & $0.85^{\mathrm{a}}$ & $1.84^{\mathrm{a}, \mathrm{b}, \mathrm{c}}$ & $10.43^{h}$ & $33.11^{1}$ \\
\hline Rosa rugosa cv 'Alba' & $1.14^{\mathrm{a}, \mathrm{b}}$ & $1.51^{\mathrm{a}, \mathrm{b}, \mathrm{c}}$ & $1.84^{\mathrm{a}, \mathrm{b}, \mathrm{c}}$ & $2.54^{b, c, d}$ & $3.63^{d, e, f}$ \\
\hline \multicolumn{6}{|c|}{$\alpha$-carotene } \\
\hline Rosa canina & $0.00^{\mathrm{a}}$ & $0.00^{\mathrm{a}}$ & $0.00^{\mathrm{a}}$ & $0.04^{a, b, c}$ & $0.05^{\mathrm{a}, \mathrm{b}, \mathrm{c}}$ \\
\hline Rosa rugosa & $0.00^{\mathrm{a}}$ & $0.00^{\mathrm{a}}$ & $0.00^{\mathrm{a}}$ & $0.00^{\mathrm{a}}$ & $0.00^{\mathrm{a}}$ \\
\hline Rosa rugosa cv 'Alba' & $0.00^{\mathrm{a}}$ & $0.00^{\mathrm{a}}$ & $0.21^{b, c}$ & $0.50^{\mathrm{d}}$ & $0.87^{\mathrm{e}}$ \\
\hline Rosa rugosa cv 'Rubra' & $0.00^{\mathrm{a}}$ & $0.00^{\mathrm{a}}$ & $0.16^{\mathrm{a}, \mathrm{b}, \mathrm{c}}$ & $0.23^{c}$ & $1.31^{\mathrm{f}}$ \\
\hline Rosa canina & $3.73^{\mathrm{a}, \mathrm{b}, \mathrm{c}, \mathrm{d}}$ & $4.24^{\beta \text { b,c,d,e }}$ & $9.32^{f}$ & $\beta$-carotene & $14.10^{\mathrm{h}}$ \\
\hline Rosa rugosa & $2.15^{\mathrm{a}, \mathrm{b}}$ & $3.38^{\mathrm{a}, \mathrm{b}, \mathrm{c}}$ & $3.57^{\mathrm{a}, \mathrm{b}, \mathrm{cd}}$ & $6.17^{\mathrm{e}}$ & $18.54^{j}$ \\
\hline Rosa rugosa cv 'Alba' & $1.50^{\mathrm{a}}$ & $1.61^{\mathrm{a}}$ & $2.60^{a, b}$ & $4.90^{\mathrm{c}, \mathrm{d}, \mathrm{e}}$ & $18.56^{j}$ \\
\hline Rosa rugosa cv 'Rubra' & $3.99 \mathrm{~b}, \mathrm{c}, \mathrm{de}$ & $5.79 \mathrm{~d}, \mathrm{e}$ & $6.00^{\mathrm{e}}$ & $8.57^{\mathrm{f}}$ & $11.59 \mathrm{~g}$ \\
\hline \multicolumn{6}{|c|}{ Total lycopene } \\
\hline Rosa canina & $1.11^{b, c}$ & $1.47^{\mathrm{c}, \mathrm{d}, \mathrm{e}}$ & $1.77^{\mathrm{e}, \mathrm{f}}$ & $2.19^{\mathrm{f}}$ & $13.64^{\mathrm{j}}$ \\
\hline Rosa rugosa & $0.42^{\mathrm{a}}$ & $0.43^{\mathrm{a}}$ & $0.63^{a, b}$ & $1.42^{c, d, e}$ & $3.85 \mathrm{~g}$ \\
\hline Rosa rugosa cv 'Alba' & $0.88^{a, b, c}$ & $1.02^{a, b, c}$ & $1.12^{b, c, d}$ & $1.74^{\mathrm{d}, \mathrm{e}, \mathrm{f}}$ & $3.53^{g}$ \\
\hline Rosa rugosa cv 'Rubra' & $1.34^{\mathrm{c}, \mathrm{d}, \mathrm{e}}$ & $1.31^{\mathrm{c}, \mathrm{d}, \mathrm{e}}$ & $0.62^{a, b}$ & $1.78^{\mathrm{e}, \mathrm{f}}$ & $3.36^{\mathrm{g}}$ \\
\hline \multicolumn{6}{|c|}{ Cis-lycopene } \\
\hline Rosa canina & $0.37^{\mathrm{a}, \mathrm{b}}$ & $0.25^{\mathrm{a}, \mathrm{b}}$ & $0.24^{\mathrm{a}}$ & $0.29 \mathrm{a}, \mathrm{b}$ & $1.40^{\mathrm{d}}$ \\
\hline Rosa rugosa & $0.16^{\mathrm{a}}$ & $0.17^{\mathrm{a}}$ & $0.33^{\mathrm{a}, \mathrm{b}}$ & $1.03^{\mathrm{c}}$ & $3.28^{f}$ \\
\hline Rosa rugosa cv 'Alba' & $0.23^{a}$ & $0.20^{\mathrm{a}}$ & $0.17^{\mathrm{a}}$ & $0.23^{\mathrm{a}}$ & $0.48^{\mathrm{a}, \mathrm{b}}$ \\
\hline Rosa rugosa cv 'Rubra' & $0.48^{\mathrm{a}, \mathrm{b}}$ & $0.61^{b}$ & $0.29^{a, b}$ & $1.37^{\mathrm{c}, \mathrm{d}}$ & $2.76^{\mathrm{e}}$ \\
\hline \multicolumn{6}{|c|}{ Trans-lycopene } \\
\hline Rosa canina & $0.74^{\mathrm{a}, \mathrm{b}, \mathrm{cd}}$ & $1.21^{\mathrm{d}, \mathrm{e}}$ & $1.53^{\mathrm{e}, \mathrm{f}}$ & $1.90^{f}$ & $12.24^{\mathrm{h}}$ \\
\hline Rosa rugosa & $0.26^{\mathrm{a}}$ & $0.26^{\mathrm{a}}$ & $0.30^{\mathrm{a}}$ & $0.39^{\mathrm{a}, \mathrm{b}}$ & $0.56^{\mathrm{a}, \mathrm{b}, \mathrm{c}}$ \\
\hline Rosa rugosa cv 'Alba' & $0.67^{\mathrm{a}, \mathrm{b}, \mathrm{c}}$ & $0.82^{b, c, d}$ & $0.95^{\mathrm{c}, \mathrm{d}}$ & $1.51^{\mathrm{e}, \mathrm{f}}$ & $3.05 \mathrm{~g}$ \\
\hline Rosa rugosa cv 'Rubra' & $0.87^{b, c, d}$ & $0.70^{a, b, c}$ & $0.32^{\mathrm{a}}$ & $0.41^{\mathrm{a}, \mathrm{b}}$ & $0.59^{a, b, c}$ \\
\hline
\end{tabular}

Note: Different letters within columns and line indicate significant differences between harvesting dates and species/cultivar, respectively $(p<0.05)$. 
As shown in Table 2, the amounts of the xanthophylls, chlorophyll and carotenes, varied substantially.

The xanthophylls such as lutein and zeaxanthin, carotenes such as $\alpha$-carotene and $\beta$-carotene, lycopene and $a$ - and b-chlorophyll were established at all stages of ripening stage and concentrations tended to change at different ripening stages.

Carotenes, likewise, $\beta$-carotene was intensively increased at Stage V. Significantly highest amount of $\beta$-carotene was determined in rosehip of Rosa rugosa and Rosa rugosa 'Alba' (18.54 mg $100 \mathrm{~g}^{-1}$ and $18.56 \mathrm{mg} 100 \mathrm{~g}^{-1}$, respectively), while lowest amount of $\beta$-carotene was in rosehip of Rosa rugosa 'Alba' at ripening Stage I (1.50 mg $\left.100 \mathrm{~g}^{-1}\right)$ (Table 2).

Significantly, the highest amount $1.31 \mathrm{mg} 100 \mathrm{~g}^{-1}$ of $\alpha$-carotene was established in Rosa rugosa 'Rubra' at the end of the experiment (Table 2). $\alpha$-carotene was not detected in rosehip of Rosa rugosa specie at all ripening stages. By the way, in the rosehip of Rosa canina was not detected at ripening Stages I, II and III, in the Rosa rugosa 'Alba' and Rosa rugosa 'Rubra' at the Stages I and II.

Naturally, most xanthophylls are yellow-orange colored pigments, especially lutein and zeaxanthin which can be found in most of the fruits and vegetables [12].

Our results showed that the significantly highest amount of lutein was established in rosehip of Rosa rugosa 'Rubra' and Rosa canina species/cultivar (11.26 mg $100 \mathrm{~g}^{-1}$ and $9.19 \mathrm{mg} 100 \mathrm{~g}^{-1}$, respectively) at ripening Stage V, while in the fruits of Rosa rugosa 'Alba' (4.25 mg $100 \mathrm{~g}^{-1}$, respectively) at Stage II, but the lowest amount was determined at the end of the experiment (Table 2). Our results coincide with Andersson et al. [11] published data.

The next identified carotenoid was zeaxanthin, the amount of this xanthophyll in the

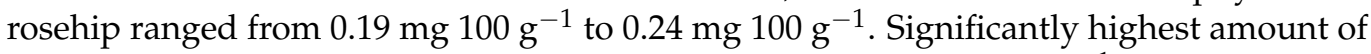
this carotenoid was determined in Rosa canina species ( $0.24 \mathrm{mg} 100 \mathrm{~g}^{-1}$, respectively) at ripening Stage IV. The ripening stage had no significant effect on the zeaxanthin amount in the rosehip of Rosa rugosa 'Alba' and was $0.20 \mathrm{mg} 100 \mathrm{~g}^{-1}$ during the course of the experiment. In rosehip fruits of Rosa rugosa the amount remained stable at the Stages II, III, IV and V (0.20 mg $100 \mathrm{~g}^{-1}$, respectively).

In our study lutein and zeaxanthin decreased/increased irregularly, depending on the ripening stages and species/cultivar. In the fruits of Rosa canina, Rosa rugosa, Rosa rugosa 'Rubra' the highest amounts of this compounds were established in fully ripe rosehip, while in the Rosa rugosa 'Alba' the highest amount was detected at the beginning of experiment, our results coincide with Andersson et al. [11] data, the highest amount of lutein and zeaxanthin were detected on the first harvesting date and the lowest on the later harvesting date.

The amounts of chlorophyll a and chlorophyll $b$ in rosehips varied depending on the ripening stage (Table 2). The amount of chlorophyll $\mathrm{b}$ in the rosehip of Rosa canina, Rosa rugosa and Rosa rugosa 'Rubra' species/cultivar decreased, and the lowest amount was established in fully ripe rosehip. In the fruits of Rosa rugosa 'Alba' the highest amount of chlorophyll b was found at the Stage II and tended decreased at Stages III, IV and V. Significantly highest amount of this chlorophyll was found in rosehip of Rosa canina (6.21 mg $100 \mathrm{~g}^{-1}$, respectively) at ripening Stage I. Andersson et al. [11] also, reported that the chlorophyll $\mathrm{b}$ decreased from the first to later harvesting dates.

However, the amount of chlorophyll a in the Rosa canina, Rosa rugosa, Rosa rugosa 'Alba' increased during the growing period and significantly highest amount was determined in Rosa canina (53.11 mg $100 \mathrm{~g}^{-1}$, respectively) at ripening Stage V.

Lycopene is an acyclic carotenoid found in great abundance in rosehips [11].

In our study, the amount of well-known antioxidant lycopene varied from $0.42 \mathrm{mg}$ $100 \mathrm{~g}^{-1}$ to $13.64 \mathrm{mg} 100 \mathrm{~g}^{-1}$ (Table 2). Our data showed that the significantly highest amount of this carotenoid was established in rosehip of Rosa canina species (13.64 mg $100 \mathrm{~g}^{-1}$, respectively) at the end of the experiment. The amount of total lycopene in rosehip fruits of Rosa canina were 3.5, 3.8 and 4.0 time higher than in the rosehip of Rosa rugosa, Rosa rugosa 'Alba' and Rosa rugosa 'Rubra'. Böhm et al. [13] reported that the 
amount of total lycopene in raw rosehips ranged from $12.9 \mathrm{mg} 100 \mathrm{~g}^{-1}$ to $35.2 \mathrm{mg} 100 \mathrm{~g}^{-1}$, Andersson et al. [11] also have found that amount of this carotene increased and the lycopene levels was 24.3 time higher on the late harvesting date.

Most of the lycopene occurs naturally in all-trans form [14]. In our study the dominant

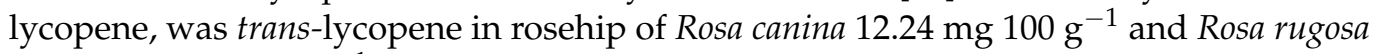
'Rubra' $2.76 \mathrm{mg} 100 \mathrm{~g}^{-1}$, while in rosehip of Rosa rugosa and Rosa rugosa 'Rubra' the major

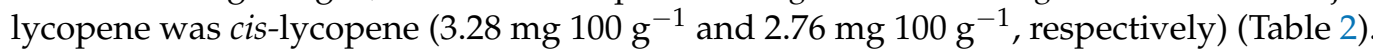
These data showed that highest amounts of cis- and trans- lycopene were in a fully ripened rosehips and showed a ratio of cis- to trans- lycopene: in the Rosa canina of 10:90, Rosa rugosa of 85:15, Rosa canina 'Alba' of 14:86 and Rosa rugosa 'Rubra' 82:18. Böhm et al. [13] investigated the raw rosehips and showed a ratio of cis-lycopene to lycopene trans-isomers of 40:60.

There are many factors influencing the isomerization of carotenoids. Heat, light, drying and structural differences are the prominent factors that affect the isomerization of carotenoids in foods [15].

\subsection{Polyphenols}

The data averaged over the two experimental years showed, that amounts of polyphenols in rosehip significantly depends on species/cultivar and ripening stages (Table 3). All rosehip species/cultivars were grown under the same conditions however, the influence of ripening stage on the accumulation of polyphenols amount in the fruits was highly variable. The rosehip of the Rosa rugosa 'Alba' and Rosa rugosa 'Rubra' showed significantly highest amounts of total polyphenols at ripening Stages I and II (110.34 mg $100 \mathrm{~g}^{-1}, 107.88 \mathrm{mg}$

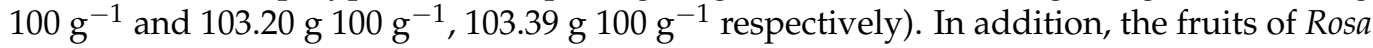
rugosa showed the lowest amounts of total polyphenols at all ripening stages, compared with the other investigated rosehip fruits (Table 3).

Table 3. Effects of ripening stage on the amounts of total polyphenols in the rosehip fruits, mg $100 \mathrm{~g}^{-1} \mathrm{DW}$.

\begin{tabular}{cccccc}
\hline \multirow{2}{*}{ h } & \multicolumn{5}{c}{ Ripening Stage } \\
\cline { 2 - 6 } & I & II & III & IV & V \\
\hline Rosa canina & $58.90^{\mathrm{b}}$ & \multicolumn{5}{c}{ Total polyphenols } \\
Rosa rugosa & $42.43^{\mathrm{a}}$ & $38.25^{\mathrm{b}, \mathrm{c}}$ & $66.50^{\mathrm{a}} \mathrm{b}, \mathrm{c}$ & $70.90^{\mathrm{b}, \mathrm{c}}$ & $70.84^{\mathrm{b}, \mathrm{c}}$ \\
Rosa rugosa cv 'Alba' & $110.34^{\mathrm{f}}$ & $107.88^{\mathrm{f}}$ & $81.22^{\mathrm{a}}$ & $42.30^{\mathrm{a}}$ & $45.97^{\mathrm{a}}$ \\
Rosa rugosa cv 'Rubra' & $103.20^{\mathrm{e}, \mathrm{f}}$ & $103.39^{\mathrm{e}, \mathrm{f}}$ & $90.20^{\mathrm{d}}$ & $87.47^{\mathrm{d}}$ & $72.74^{\mathrm{c}}$ \\
\hline
\end{tabular}

Note: Different letters within columns and line indicate significant differences between harvesting dates and species/cultivar, respectively $(p<0.05)$.

Najda and Buczkowska [16] studied the chemical composition of Rosa species—Rosa californica, Rosa $\times$ damascena, Rosa rugosa, Rosa spinosissima, and Rosa villosa. Researchers found that the polyphenol amount had highly diverse in these species, the highest amount of total phenolics compounds were found in Rosa rugosa and Rosa villosa (215.14 mg

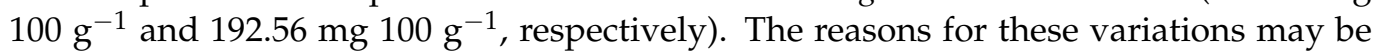
due to diversely climatic and environmental factors, including light, temperature, soil nutrients and maturity of the rosehip which may affect the metabolism and conversions of polyphenols [16].

The phenolic acid and flavonoid amounts were quantified in two species and two cultivars of rosehip at different ripening stage by HPLC method. Five phenolic acids, including gallic, chlorogenic, caffeic, p-coumaric, ferulic and five flavonoids, including rutin, astragalin, luteolin, quercetin, isoquercetin were investigated in this study.

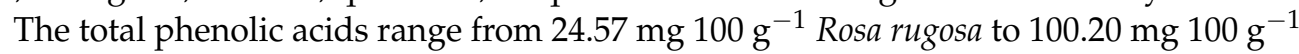
in the Rosa rugosa 'Alba' species/cultivar (Table 4). Our data showed that the genotype and ripening stage significantly influenced the amount of total phenolic acid. Demir et al. [17] 
investigated that the total phenolic amount of rosehip species changed significantly, depending on genetic variation and the highest and lowest levels of total phenolic compounds were determined in Rosa dumalis (52.94 mg $100 \mathrm{~g}^{-1}$, respectively) and Rosa canina (31.08 mg $100 \mathrm{~g}^{-1}$, respectively) samples. Howard et al. [18] detected that in blueberry, variation in phenolic composition among genotypes was much greater than that found during the growing seasons. In a study performed by Adamczak et al. [19], the authors pointed out that the phenolic acids and flavonoids are important for chemotaxonomy.

Table 4. Effects of ripening stage on the amounts of phenolic acids in the rosehip fruits, $\mathrm{mg} 100 \mathrm{~g}^{-1} \mathrm{DW}$.

\begin{tabular}{|c|c|c|c|c|c|}
\hline \multirow{2}{*}{ Samples } & \multicolumn{5}{|c|}{ Ripening Stage } \\
\hline & I & II & III & IV & $\mathbf{V}$ \\
\hline \multicolumn{6}{|c|}{ Total phenolic acid } \\
\hline Rosa canina & $52.30^{\mathrm{b}}$ & $53.21^{\mathrm{b}}$ & $57.08^{b}$ & $58.08^{b}$ & $59.60^{b}$ \\
\hline Rosa rugosa & $28.59^{\text {a }}$ & $24.93^{\mathrm{a}}$ & $24.57^{\mathrm{a}}$ & $24.81^{\mathrm{a}}$ & $27.24^{\mathrm{a}}$ \\
\hline Rosa rugosa cv 'Alba' & $100.20^{\mathrm{d}}$ & $96.57^{\mathrm{d}}$ & $76.84^{c}$ & $75.79^{c}$ & $58.20^{b}$ \\
\hline Rosa rugosa cv 'Rubra' & $91.87^{\mathrm{d}}$ & $89.90^{\mathrm{d}}$ & $76.49^{c}$ & $73.29^{c}$ & $77.04^{c}$ \\
\hline \multicolumn{6}{|c|}{ Gallic } \\
\hline Rosa canina & $20.52^{b, c}$ & $22.69^{b, c}$ & $22.62^{b, c}$ & $21.29 \mathrm{~b}, \mathrm{c}$ & $19.88^{b}$ \\
\hline Rosa rugosa & $6.42^{\mathrm{a}}$ & $6.40^{\mathrm{a}}$ & $3.44^{\mathrm{a}}$ & $3.03^{\mathrm{a}}$ & $2.77^{\mathrm{a}}$ \\
\hline Rosa rugosa cv 'Alba' & $84.89 \mathrm{j}$ & $78.06^{j}$ & $51.55^{\mathrm{e}, \mathrm{f}}$ & $47.81^{\mathrm{e}, \mathrm{f}}$ & $26.21^{b, c}$ \\
\hline \multicolumn{5}{|c|}{ Chlorogenic } & $27.60^{b, c}$ \\
\hline Rosa canina & $12.38^{\mathrm{g}}$ & $13.57^{\mathrm{h}}$ & $17.18^{\mathrm{k}}$ & $19.01^{1}$ & $21.57 \mathrm{~m}$ \\
\hline Rosa rugosa & $9.18^{\mathrm{f}}$ & $7.34^{\mathrm{d}, \mathrm{e}}$ & $7.54^{\mathrm{e}}$ & $5.60^{b, c}$ & $5.02^{b}$ \\
\hline Rosa rugosa cv 'Alba' & $4.65^{b}$ & $7.27^{\mathrm{d}, \mathrm{e}}$ & $15.94^{j}$ & $19.49^{1}$ & $22.10^{\mathrm{m}}$ \\
\hline Rosa rugosa cv 'Rubra' & $3.21^{\mathrm{a}}$ & $5.20^{b}$ & $7.97^{\mathrm{e}}$ & $7.31 \mathrm{~d}, \mathrm{e}$ & $6.50^{\mathrm{c}, \mathrm{d}}$ \\
\hline \multicolumn{6}{|c|}{ Ferulic } \\
\hline Rosa canina & $2.59^{a, b}$ & $2.96^{\mathrm{a}, \mathrm{b}, \mathrm{c}}$ & $4.09^{c}$ & $6.19^{\mathrm{d}, \mathrm{e}}$ & $7.66^{f}$ \\
\hline Rosa rugosa & $2.00^{\mathrm{a}}$ & $3.61^{b, c}$ & $6.82^{e, f}$ & $9.70^{\mathrm{g}}$ & $13.05^{\mathrm{h}}$ \\
\hline Rosa rugosa cv 'Alba' & $1.91^{\mathrm{a}}$ & $2.68^{\mathrm{a}, \mathrm{b}}$ & $2.93^{a, b, c}$ & $3.48^{b, c}$ & $5.58^{\mathrm{d}}$ \\
\hline Rosa rugosa cv 'Rubra' & $13.95^{\mathrm{h}}$ & $17.07^{j}$ & $18.53^{\mathrm{k}}$ & $26.68^{1}$ & $36.95^{\mathrm{m}}$ \\
\hline \multicolumn{6}{|c|}{ Caffeic } \\
\hline Rosa canina & $11.31^{j}$ & $10.23^{j}$ & $10.08^{h, j}$ & $8.87^{\mathrm{g}, \mathrm{h}}$ & $7.94^{\mathrm{g}}$ \\
\hline Rosa rugosa & $7.96^{\mathrm{g}}$ & $4.79^{c, d, e}$ & $4.81^{\mathrm{c}, \mathrm{d}, \mathrm{e}}$ & $4.54^{\mathrm{c}, \mathrm{d}}$ & $4.44^{\mathrm{c}, \mathrm{d}}$ \\
\hline Rosa rugosa cv 'Alba' & $6.35^{f}$ & $5.98^{\mathrm{e}, \mathrm{f}}$ & $3.88^{b, c}$ & $2.78^{a, b}$ & $2.25^{\mathrm{a}}$ \\
\hline \multicolumn{6}{|c|}{$P$-coumaric } \\
\hline Rosa canina & $5.55^{1}$ & $3.76^{\mathrm{j}}$ & $3.12^{\mathrm{h}}$ & $2.73^{\mathrm{e}, \mathrm{f}, \mathrm{g}, \mathrm{h}}$ & $2.55^{\mathrm{c}, \mathrm{d}, \mathrm{e}, \mathrm{f}}$ \\
\hline Rosa rugosa & $3.03 \mathrm{~g}, \mathrm{~h}$ & $2.79 \mathrm{e}, \mathrm{f}, \mathrm{g}, \mathrm{h}$ & $1.96^{\mathrm{a}, \mathrm{b}}$ & $1.93^{\mathrm{a}}$ & $1.96^{\mathrm{a}, \mathrm{b}}$ \\
\hline Rosa rugosa cv 'Alba' & $2.39^{\mathrm{a}, \mathrm{b}, \mathrm{c}, \mathrm{d}, \mathrm{e}}$ & $2.58^{\mathrm{d}, \mathrm{e}, \mathrm{f}, \mathrm{g}}$ & $2.54^{\mathrm{c}, \mathrm{d}, \mathrm{e}, \mathrm{f}}$ & $2.23^{\mathrm{a}, \mathrm{b}, \mathrm{c}, \mathrm{d}}$ & $2.06^{a, b}$ \\
\hline Rosa rugosa cv 'Rubra' & $5.37^{\mathrm{k}, 1}$ & $4.90^{\mathrm{k}}$ & $2.93^{\mathrm{f}, \mathrm{g}, \mathrm{h}}$ & $2.42^{b, c, d, e}$ & $2.10^{\mathrm{a}, \mathrm{b}, \mathrm{c}}$ \\
\hline
\end{tabular}

Note: different letters within columns and line indicate significant differences between harvesting dates and species/cultivar, respectively $(p<0.05)$.

The amounts of total phenolic acids in Rosa rugosa 'Alba' and Rosa rugosa 'Rubra' fruits significantly decreased with the maturity, while significantly lowest this amounts were established in Rosa canina and Rosa rugosa, however remained stable during the ripening stages and did not vary significantly.

Other authors investigated the apples grown under organic and integrated conditions and established that organic apples had higher total phenolic amount than the integrated grown. The reason for higher phenolic levels in organically grown apples lies in the fact that the trees are exposed to various stress factors, like diseases, pests, lack of mineral nutrients, etc., which induce the accumulation of phenolic compounds [20].

Our study showed that the main phenolic acid was gallic acid, which content ranged

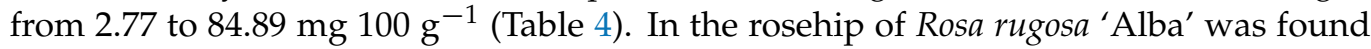
significantly the highest amount of this acid at ripening Stages I and II ( 84.89 and $78.06 \mathrm{mg}$ 
$100 \mathrm{~g}^{-1}$, respectively). Nadpal et al. [21] have also found that the gallic acid was the dominant phenolic acid and in rosehip of Rosa arvensis was established ten times higher amount of gallic acid, than in Rosa canina extracts. Elmastaş et al. [22] investigated three rosehip species Rosa dumalis, Rosa canina and Rosa villosa and reported that the amount of gallic acid range from 1.17 to $57.5 \mathrm{mg} \mathrm{kg}^{-1}$ to 0.12 to $5.75 \mathrm{mg} 100 \mathrm{~g}^{-1}$.

The second dominant phenolic acid in rosehip was found the chlorogenic acid and ranged from 3.21 to $22.10 \mathrm{mg} 100 \mathrm{~g}^{-1}$ (Table 4). The results indicated that chlorogenic acid amount increase depending on the rosehip species and ripening stage. The rosehip of Rosa rugosa 'Alba' and Rosa canina sample had highest amounts of this acid at ripening Stage V. In the fruits of the Rosa canina, Rosa rugosa 'Alba' and Rosa rugosa 'Rubra' were established highest chlorogenic acid amount at ripening Stage V (21.57, 22.10 and $6.50 \mathrm{mg} 100 \mathrm{~g}^{-1}$, respectively), while the highest amount of this acid was determined in rosehip of Rosa

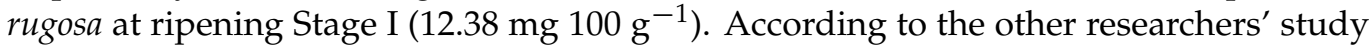
amount of chlorogenic acid range from 7.55 to $12.11 \mathrm{mg} 100 \mathrm{~g}^{-1}$ in fully ripe rosehip [17].

The next determined phenolic acid was ferulic acid (Table 4). Our result showed that the ferulic acid amount in the rosehip ranged from 1.91 to $36.95 \mathrm{mg} 100 \mathrm{~g}^{-1}$. The significantly highest ferulic acid amounts in the fruits of Rosa rugosa 'Rubra' were determined at all ripening stages comparing with other rosehip. The study by Elmastaş et al. [22] established that the ferulic acid content of three rosehip species Rosa dumalis, Rosa canina,

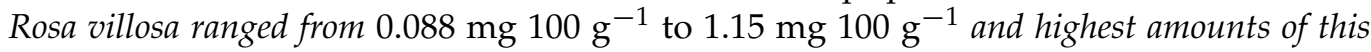
acid were found in fully ripe rosehip. Demir et al. [17] investigated five rosehip species and

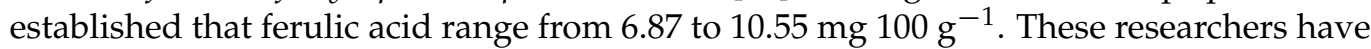
found that highest amount of this acid was in fruits of Rosa canina species. In our study the ferulic acid concentration tended to increase with ripening stage and peaked highest amount at the ripening Stage $\mathrm{V}$ in all studied species.

In all studied rosehips, the amount of caffeic acid decreased depending on the ripening stage (Table 4). Significantly the highest amount of this acid was determined in rosehip of Rosa canina (11.31 mg $100 \mathrm{~g}^{-1}$, respectively) at the beginning of the experiment, while lowest amount was found at the end of experiment. In a study by Nowak [5] determined that in Rosa coriifolia the amount of caffeic acid-2.1 mg $100 \mathrm{~g}^{-1}$, in rosehip of Rosa rugosa$8.3 \mathrm{mg} 100 \mathrm{~g}^{-1}$. Elmastaş et al., [22] reported that in all studied rosehip species the caffeic acid was the most abundance. The highest amount of this acid was found in rosehip of Rosa dumalis at first harvest time, Rosa canina at Stage V and Rosa villosa at the second

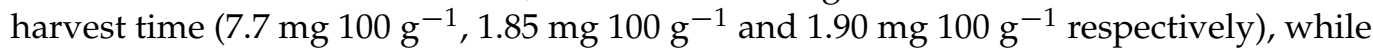
our study showed that in all investigated rosehip species/cultivars, highest amounts were established at ripening Stage I.

The $p$-coumaric acid also were decreased depending on the harvesting time. Rosa canina and Rosa rugosa 'Rubra' fruits had significantly highest amounts of this acid at ripening Stage I (5.55 mg $100 \mathrm{~g}^{-1}$ and $5.37 \mathrm{mg} 100 \mathrm{~g}^{-1}$, respectively), while the lowest amount was found at the end of the experiment in all studied species/cultivar (Table 4). Demir and other researchers [17] established amount of $p$-coumaric in the fruits of Rosa

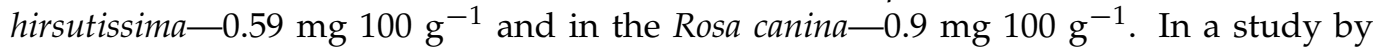
Elmastaş et al. [22], the highest amount of this acid was established at ripening Stage II in rosehip of Rosa dumalis specie, and at Stage V in Rosa canina and Rosa villosa, therefore, these results were in contrast with our results.

The amount of total flavonoid was found to range from $6.61 \mathrm{mg} 100 \mathrm{~g}^{-1}$ in the rosehip

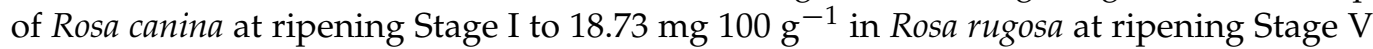
(Table 5). The amount of total flavonoid decreased and increased depending on the ripening stage and species/cultivar. 
Table 5. Effects of ripening stage on the amounts of flavonoids in the rosehip fruits, $\mathrm{mg} 100 \mathrm{~g}^{-1} \mathrm{DW}$.

\begin{tabular}{|c|c|c|c|c|c|}
\hline \multirow[b]{2}{*}{ Samples } & \multicolumn{5}{|c|}{ Ripening Stage } \\
\hline & $\mathbf{I}$ & II & III & IV & $\mathbf{V}$ \\
\hline \multicolumn{6}{|c|}{ Total flavonoids } \\
\hline Rosa canina & $6.61^{\mathrm{a}}$ & $7.04^{\mathrm{a}}$ & $9.42^{b}$ & $12.81^{\mathrm{e}, \mathrm{f}}$ & $11.24^{\mathrm{c}, \mathrm{d}}$ \\
\hline Rosa rugosa & $13.82^{\mathrm{f}, \mathrm{g}, \mathrm{h}}$ & $13.95^{\mathrm{f}, \mathrm{g}, \mathrm{h}}$ & $16.66^{\mathrm{j}}$ & $17.50 \mathrm{j}, \mathrm{k}$ & $18.73^{\mathrm{k}}$ \\
\hline Rosa rugosa cv 'Alba' & $10.15^{b, c}$ & $11.32^{b, c}$ & $11.81^{\mathrm{d}, \mathrm{e}}$ & $13.04^{\mathrm{e}, \mathrm{f}, \mathrm{g}}$ & $14.54^{\mathrm{h}}$ \\
\hline Rosa rugosa cv 'Rubra' & $11.33^{b, c}$ & $13.50^{\mathrm{f}, \mathrm{g}, \mathrm{h}}$ & $13.72^{\mathrm{f}, \mathrm{g}, \mathrm{h}}$ & $14.18^{\mathrm{g}, \mathrm{h}}$ & $16.50^{j}$ \\
\hline \multicolumn{6}{|c|}{ Rutin } \\
\hline Rosa canina & $1.69^{\mathrm{a}}$ & $2.27^{\mathrm{a}}$ & $4.65^{b}$ & $8.01 \mathrm{e}, \mathrm{f}$ & $6.12^{c, d}$ \\
\hline Rosa rugosa & $8.71^{\mathrm{f}, \mathrm{g}, \mathrm{h}}$ & $8.97^{\mathrm{f}, \mathrm{g}, \mathrm{h}}$ & $11.64^{j}$ & $12.44^{j}$ & $13.65^{\mathrm{k}}$ \\
\hline Rosa rugosa cv 'Alba' & $5.06^{b, c}$ & $6.42^{\mathrm{d}}$ & $7.06^{\mathrm{d}, \mathrm{e}}$ & $8.25^{\mathrm{e}, \mathrm{f}, \mathrm{g}}$ & $9.61^{\mathrm{h}}$ \\
\hline Rosa rugosa cv 'Rubra' & $6.38^{\mathrm{d}}$ & $8.75^{f, g, h}$ & $8.92^{\mathrm{f}, \mathrm{g}, \mathrm{h}}$ & $9.31^{\mathrm{g}, \mathrm{h}}$ & $11.68^{j}$ \\
\hline \multicolumn{6}{|c|}{ Quercetin } \\
\hline Rosa canina & $1.38^{\mathrm{a}}$ & $1.43^{\mathrm{a}, \mathrm{b}, \mathrm{c}}$ & $1.72^{\mathrm{e}, \mathrm{f}}$ & $1.76^{\mathrm{f}}$ & $2.00^{h, j}$ \\
\hline Rosa rugosa & $1.40^{\mathrm{a}, \mathrm{b}}$ & $1.43^{\mathrm{a}, \mathrm{b}, \mathrm{c}}$ & $1.47^{b, c}$ & $1.50^{\mathrm{c}, \mathrm{d}}$ & $1.57^{\mathrm{d}}$ \\
\hline Rosa rugosa cv 'Alba' & $1.88^{g}$ & $1.94^{\mathrm{g}, \mathrm{h}}$ & $2.02^{\mathrm{j}}$ & $2.17^{\mathrm{k}}$ & $2.28^{1}$ \\
\hline Rosa rugosa cv 'Rubra' & $1.37^{\mathrm{a}}$ & $1.46^{\mathrm{b}, \mathrm{c}}$ & $1.65^{\mathrm{e}}$ & $1.75^{\mathrm{f}}$ & $1.91^{\mathrm{g}}$ \\
\hline \multicolumn{6}{|c|}{ Luteolin } \\
\hline Rosa canina & $1.70^{\mathrm{a}, \mathrm{b}, \mathrm{c}, \mathrm{d}, \mathrm{e}}$ & $1.71^{b, c, d, e}$ & $1.74^{\mathrm{f}, \mathrm{g}}$ & $1.73^{\mathrm{d}, \mathrm{e}, \mathrm{f}}$ & $1.78^{h, j}$ \\
\hline Rosa rugosa & $1.69^{a, b, c}$ & $1.70^{a, b, c, d}$ & $1.71^{b, c, d, e}$ & $1.73^{\mathrm{d}, \mathrm{e}, \mathrm{f}}$ & $1.76^{\mathrm{g}, \mathrm{h}}$ \\
\hline Rosa rugosa cv 'Alba' & $1.67^{\mathrm{a}}$ & $1.68^{\mathrm{a}, \mathrm{b}}$ & $1.71^{b, c, d, e f}$ & $1.72^{d, e, f}$ & $1.74^{\mathrm{f}, \mathrm{g}}$ \\
\hline Rosa rugosa cv 'Rubra' & $1.71^{b, c, d, e f}$ & $1.73^{e, f, g}$ & $1.79 \mathrm{~h}, \mathrm{j}$ & $1.78^{h, j}$ & $1.80^{\mathrm{j}}$ \\
\hline \multicolumn{6}{|c|}{ Astragalin } \\
\hline Rosa canina & $0.96^{\mathrm{c}, \mathrm{d}}$ & $1.00^{\mathrm{d}, \mathrm{e}}$ & $1.08^{\mathrm{d}, \mathrm{e}, \mathrm{f}}$ & $1.17^{\mathrm{e}, \mathrm{f}, \mathrm{g}}$ & $1.29 \mathrm{~g}$ \\
\hline Rosa rugosa & $0.68^{\mathrm{a}}$ & $0.68^{a}$ & $1.02^{\mathrm{d}, \mathrm{e}, \mathrm{f}}$ & $1.16^{\mathrm{e}, \mathrm{f}, \mathrm{g}}$ & $1.46^{\mathrm{h}}$ \\
\hline Rosa rugosa cv 'Alba' & $0.68^{a}$ & $0.71^{\mathrm{a}, \mathrm{b}}$ & $0.74^{\mathrm{a}, \mathrm{b}}$ & $0.78^{\mathrm{a}, \mathrm{b}}$ & $0.81^{\mathrm{a}, \mathrm{b}, \mathrm{c}}$ \\
\hline \multicolumn{6}{|c|}{ Isoquercetin } \\
\hline Rosa canina & $0.87^{f}$ & $0.64^{\frac{1}{d}}$ & $0.23^{b, c}$ & $0.14^{\mathrm{a}, \mathrm{b}, \mathrm{c}}$ & $0.05^{\mathrm{a}}$ \\
\hline Rosa rugosa & $1.34^{\mathrm{h}}$ & $0.18^{\mathrm{g}}$ & $0.81^{\mathrm{e}, \mathrm{f}}$ & $0.66^{\mathrm{d}, \mathrm{e}}$ & $0.28^{c}$ \\
\hline Rosa rugosa cv 'Alba' & $0.85^{\mathrm{f}}$ & $0.87^{\mathrm{d}}$ & $0.27^{\mathrm{c}}$ & $0.12^{\mathrm{a}, \mathrm{b}}$ & $0.09^{a, b}$ \\
\hline Rosa rugosa cv 'Rubra' & $1.19 \mathrm{~g}, \mathrm{~h}$ & $0.87^{\mathrm{f}}$ & $0.65^{\mathrm{d}}$ & $0.56^{\mathrm{d}}$ & $0.27^{\mathrm{c}}$ \\
\hline
\end{tabular}

Note: different letters within columns and line indicate significant differences between harvesting dates and species/cultivar, respectively $(p<0.05)$.

Other authors were established that the total flavonoid amount in rosehip fruits of Rosa canina increased at the fourth ripening stage and in fifth ripening stage the amount was decreased. It has been reported that the total flavonoid compounds ranged as 300$620 \mathrm{mg} \mathrm{kg}^{-1}$ in Rosa canina genotypes [22]. Bhave et al. [23] had established that the amount of the total flavonoid ranged from $671 \mathrm{mg} \mathrm{kg}^{-1}$ to $914 \mathrm{mg} \mathrm{kg}^{-1}$ in rosehip samples of Rosa spinosissima and Rosa sherardii.

In the rosehip of Rosa rugosa the amounts of total flavonoids were increased at ripening Stage II, at ripening Stages III and IV decreased, but in ripening Stage V the total amount of flavonoid increased and, in this ripening, stage was found significantly highest amount (18.73 mg $100 \mathrm{~g}^{-1}$, respectively) compared with others studied species/cultivar. Skrypnik et al. [24] established that the total flavonoid content in fruits of Rosa rugosa were 1.5-1.7 times higher than in the fruit of Rosa canina and the ripening stage had significant influence on flavonoids content and maximal content was established in half-ripe fruits.

In contrast, in all ripening stages the amount of the total flavonoid in rosehip cultivar of Rosa rugosa 'Alba' and Rosa rugosa 'Rubra' increased and highest amount was established at ripening Stage V (Table 5). However, there is no published research about antioxidants compounds in the rosehip fruits of Rosa rugosa 'Rubra' and Rosa rugosa 'Alba' cultivar.

In addition, in this study were established the amounts of individual flavonoid according to the ripening stage and species/cultivar (Table 5). Our data showed that the dominant

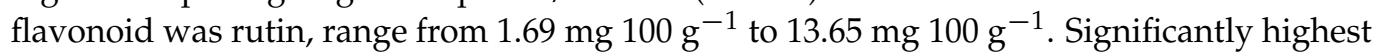


amount was established in the rosehip of Rosa rugosa at ripening Stage V $\left(13.65 \mathrm{mg} 100 \mathrm{~g}^{-1}\right.$, respectively). According to the other research data this flavonoid amount ranged from

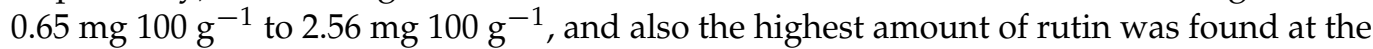
fifth harvest time [22].

The next significant flavonoid in rosehip fruits was detected in quercetin which ranged from $1.38 \mathrm{mg} 100 \mathrm{~g}^{-1}$ to $2.28 \mathrm{mg} 100 \mathrm{~g}^{-1}$. Our study showed that the significantly highest amount of quercetin was determined in rosehip of Rosa rugosa 'Alba' at ripening Stage V.

The significantly highest amount of luteolin was determined in the rosehip of Rosa rugosa 'Rubra' and Rosa canina at the end of experiment $\left(1.80 \mathrm{mg} 100 \mathrm{~g}^{-1}\right.$ and $1.78 \mathrm{mg}$ $100 \mathrm{~g}^{-1}$, respectively).

The astragalin increased during ripening stages. Among all investigated rosehip species/cultivar in the Rosa rugosa was established significantly highest astragalin amount at ripening Stage V (1.46 mg $100 \mathrm{~g}^{-1}$, respectively). However, there are no studies on astragalin amount of the rosehip as well as the influence of ripening stages.

Our results showed that the isoquercetin amount in the rosehip ranged from $0.05 \mathrm{mg}$ $100 \mathrm{~g}^{-1}$ to $1.34 \mathrm{mg} 100 \mathrm{~g}^{-1}$. This flavonoid decreased in all investigated rosehip during ripening. Significantly highest amounts were found in Rosa rugose species at ripening stages I (1.34 mg $100 \mathrm{~g}^{-1}$, respectively). Stănilă et al. [25] identified this compound in Rosa canina species.

\subsection{Vitamin $C$}

Vitamin $C$ is one of the most important water-soluble vitamins with strong antioxidant activity. It is an antioxidant that protects body from free radical damage also vitamin $\mathrm{C}$ protects the immune system, reduces the severity of allergic reactions and helps to fight off infections [26].

The vitamin $C$ amounts of foods is usually considered to be the sum of the AA (ascorbic acid) and DHAA (1-dehydroascorbic acid) [27].

AA is the principal biologically active form but 1-dehydroascorbic acid (DHA), an oxidation product, and also exhibits biological activity. Since DHA can be easily converted into AA in the human body it is important to measure both AA and DHA in fruits and vegetables for vitamin C activity [28].

While there have been many studies on the AA content of fruits, berries and vegetables, relatively few have been reported on the content of the two forms of vitamin $\mathrm{C}, \mathrm{AA}$ and DHA. Our data showed the wide variation in the amount among of AA and DHA (Table 6), the amounts ranged from 839.18 to $1972.63 \mathrm{mg} 100 \mathrm{~g}^{-1}$ and from 291.93 to $1063.45 \mathrm{mg}$ $100 \mathrm{~g}^{-1}$, respectively.

In the present study the data averaged over the two experimental years showed that

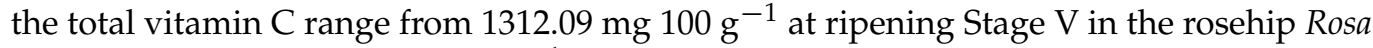
rugosa 'Alba' to $3036.08 \mathrm{mg} 100 \mathrm{~g}^{-1}$ and at Stage I in the rosehip of Rosa rugosa (Table 6).

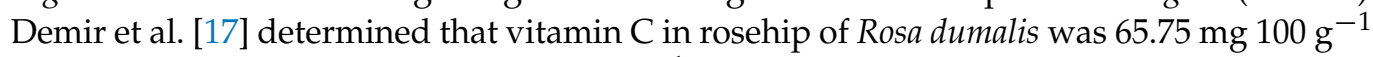

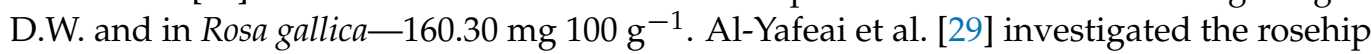
of Rosa rugosa species of three maturity stages (green, orange, red) and determined that the highest amount of ascorbic acid was in orange color rosehip and vitamin $C$ amount ranged

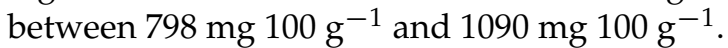

In general, our data showed that in rosehip of Rosa Canina, Rosa rugosa and Rosa rugosa 'Alba' had the highest amount of vitamin C and was found at ripening Stage I $(2060.67 \mathrm{mg}$

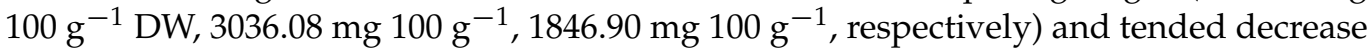
with ripening stage, while in the rosehip of Rosa rugosa 'Rubra' highest amount of this antioxidant was established at the end of the experiment (2095.22 $\mathrm{mg} 100 \mathrm{~g}^{-1}$, respectively).

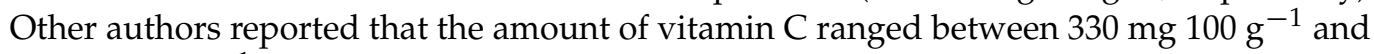
$535 \mathrm{mg} 100 \mathrm{~g}^{-1}$ [30]. Kaack and Kuhn [31] have reported that vitamin C of various Rosa

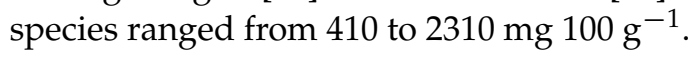




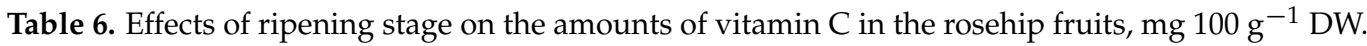

\begin{tabular}{ccccc}
\hline Samples & Ripening Stage & AA & DHA & Total Vitamin C \\
\hline \multirow{3}{*}{ Rosa canina } & I & $1251.74^{\mathrm{e}}$ & $808.94^{\mathrm{k}}$ & $2060.67^{\mathrm{f}}$ \\
& II & $1338.80^{\mathrm{e}, \mathrm{f}}$ & $574.68^{\mathrm{f}, \mathrm{g}}$ & $1913.48^{\mathrm{d}, \mathrm{e}}$ \\
& III & $1152.22^{\mathrm{c}, \mathrm{d}}$ & $377.53^{\mathrm{b}, \mathrm{c}}$ & $1529.75^{\mathrm{b}}$ \\
& IV & $1351.74^{\mathrm{f}}$ & $407.19^{\mathrm{c}, \mathrm{d}}$ & $1758.5^{\mathrm{c}}$ \\
& V & $1248.18^{\mathrm{d}, \mathrm{e}}$ & $325.95^{\mathrm{a}, \mathrm{b}}$ & $1574.13^{\mathrm{b}}$ \\
\hline \multirow{2}{*}{ Rosa rugosa } & I & $1972.63^{\mathrm{k}}$ & $1063.45^{\mathrm{m}}$ & $3036.08^{\mathrm{k}}$ \\
& II & $1879.86^{\mathrm{k}}$ & $946.45^{\mathrm{l}}$ & $2826.30^{\mathrm{j}}$ \\
& III & $1756.73^{\mathrm{j}}$ & $653.65^{\mathrm{h}, \mathrm{j}}$ & $2410.38^{\mathrm{h}}$ \\
& IV & $1658.76^{\mathrm{h}, \mathrm{j}}$ & $602.78^{\mathrm{f}, \mathrm{g}, \mathrm{h}}$ & $2261.54^{\mathrm{g}}$ \\
Rosa rugosa cv & V & $1533.24^{\mathrm{g}}$ & $702.04^{\mathrm{j}}$ & $2235.27^{\mathrm{g}}$ \\
'Alba' & I & $1139.93^{\mathrm{c}}$ & $706.97^{\mathrm{j}}$ & $1846.90^{\mathrm{c}, \mathrm{d}}$ \\
& II & $1098.93^{\mathrm{a}, \mathrm{b}}$ & $652.14^{\mathrm{g}, \mathrm{h}, \mathrm{j}}$ & $1751.06^{\mathrm{c}}$ \\
& III & $1015.18^{\mathrm{b}}$ & $598.55^{\mathrm{f}, \mathrm{g}, \mathrm{h}}$ & $1613.74^{\mathrm{b}}$ \\
& IV & $878.742^{\mathrm{a}}$ & $526.56^{\mathrm{e}, \mathrm{f}}$ & $1405.30^{\mathrm{a}}$ \\
& V & $839.18^{\mathrm{a}}$ & $472.91^{\mathrm{d}, \mathrm{e}}$ & $1312.09^{\mathrm{a}}$ \\
\hline \multirow{2}{*}{ Rosa rugosa cv } & I & $1646.23^{\mathrm{h}}$ & $350.09^{\mathrm{a}, \mathrm{b}, \mathrm{c}}$ & $1996.31^{\mathrm{e}, \mathrm{f}}$ \\
'Rubra' & II & $1534.19^{\mathrm{g}}$ & $323.28^{\mathrm{a}, \mathrm{b}}$ & $1857.47^{\mathrm{c}, \mathrm{d}}$ \\
& III & $1547.13^{\mathrm{g}}$ & $291.93^{\mathrm{a}}$ & $1839.06^{\mathrm{c}, \mathrm{d}}$ \\
& IV & $1543.37^{\mathrm{g}}$ & $272.67^{\mathrm{a}}$ & $1816.04^{\mathrm{c}, \mathrm{d}}$ \\
& V & $1479.12^{\mathrm{g}}$ & $616.09^{\mathrm{g}, \mathrm{h}}$ & $2095.22^{\mathrm{f}}$ \\
\hline
\end{tabular}

Note: different letters within columns and line indicate significant differences between harvesting dates and species/cultivar, respectively $(p<0.05)$.

In species/cultivar of rosehip Rosa rugosa, Rosa rugosa 'Alba' and Rosa rugosa 'Rubra' highest AA amounts were found at ripening Stage I (1972.63 mg $100 \mathrm{~g}^{-1}, 1139.93 \mathrm{mg}$ $100 \mathrm{~g}^{-1}, 1646.23 \mathrm{mg} 100 \mathrm{~g}^{-1}$, respectively), while in Rosa canina it was found at ripening Stage IV (1351.74 mg $100 \mathrm{~g}^{-1}$ ). The highest amounts of DHA in rosehip of Rosa canina, Rosa rugosa, Rosa rugosa "Alba' were established also at ripening Stage I (808.94 mg $100 \mathrm{~g}^{-1}$, $1063.45 \mathrm{mg} 100 \mathrm{~g}^{-1}, 706.97 \mathrm{mg} 100 \mathrm{~g}^{-1}$, respectively), while in the Rosa rugosa 'Rubra' at

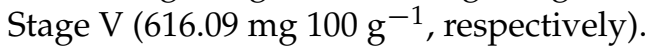

Nojavan et al. [32] reported, that in the frozen rosehip samples the content of AA was obtained in unripe rosehip-18.0 mg $100 \mathrm{~g}^{-1}$, in half-ripe rosehip-175.0 mg $100 \mathrm{~g}^{-1}$, in fully ripened rosehip- $417.5 \mathrm{mg} 100 \mathrm{~g} \mathrm{~g}^{-1}$ and in the mild-temperature-drying, the concentrations were in unripe dog rose $-3.0 \mathrm{mg} 100 \mathrm{~g}^{-1}$, in half-ripe dog rose- $34.0 \mathrm{mg}$

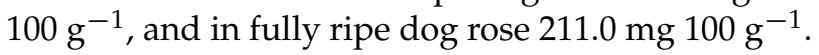

Ercişli and Eşitken [33] investigated 12 different rosehip selections and established

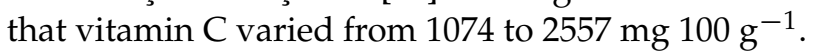

In accordance with other reports, in organic raspberry, there was established a higher

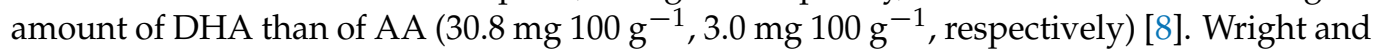
Kader [34] carried out the experiment with persimmons and established that amount of the

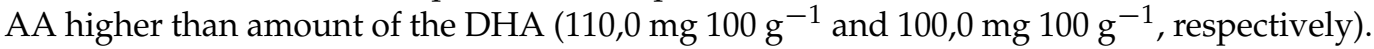

The content of vitamin $C$ in fruits and vegetables can be influenced by various factors such as genotypic differences, preharvest climatic conditions and cultural practices, maturity and harvesting methods, and postharvest handling procedures [28].

\section{Conclusions}

The results of the study showed that the wide variation in the amounts of carotenoids, polyphenols, and vitamin $C$ depending of rosehip fruit species and cultivars. The significantly highest concentrations of total flavonoids and vitamin $C$ were established in the rosehip fruits of Rosa rugosa, while phenolic acids in Rosa rugosa 'Alba' and Rosa rugosa 'Rubra'.

The results also demonstrated that the ripening stage had significant effect on the amounts of bioactive compounds in rosehip. The significantly highest concentrations of 
total carotenoids were observed at the ripening Stage V. While highest amounts of phenolic acid were determined at ripening Stages I and II, and flavonoids at Stage IV. In rosehip fruits, significantly, the highest amount of vitamin $\mathrm{C}$ was established at ripening Stage I. Our research confirms that rosehip fruits are a good source of bioactive compounds.

Author Contributions: Conceptualization, J.K. and B.M.; methodology, J.K., B.M., E.H.; software, B.M.; validation, J.K., D.L. and E.H.; formal analysis, B.M. and J.K.; investigation, B.M. and J.K.; resources, B.M.; data curation, B.M. and J.K.; writing—original draft preparation, B.M.; writingreview and editing, B.M., D.L., E.H. and J.K.; visualization, B.M. and J.K.; supervision, J.K.; project administration, D.L.; funding acquisition, B.M. and J.K. All authors have read and agreed to the published version of the manuscript.

Funding: This research received no external funding.

Conflicts of Interest: The authors declare no conflict of interest.

\section{References}

1. Singh, P.; Goyal, G.K. Dietary lycopene: Its properties and anticarcinogenic effects. Compr. Rev. Food Sci. Food Saf. 2008, 7, 255-270. [CrossRef]

2. Patel, S. Rose hip as an underutilized functional food: Evidence-based review. Trends Food Sci. Tech. 2017, 63, 29-38. [CrossRef]

3. Kulaitienè, J.; Medveckienè, B.; Levickienė, D.; Vaitkevičienè, N.; Makarevičienė, V.; Jarienė, E. Changes in Fatty Acids Content in Organic Rosehip (Rosa spp.) Seeds during Ripening. Plants 2020, 9, 1793. [CrossRef]

4. Barros, L.; Carvalho, A.M.; Ferreira, I.C.F.R. Exotic fruits as a source of important phytochemicals: Improving the traditional use of Rosa canina fruits in Portugal. Int. Food Res. J. 2011, 44, 2233-2236. [CrossRef]

5. Nowak, R. Comparative study of phenolic acids in pseudofruits of some species of roses. Acta Pol. Pharm. 2006, 63, 281-288.

6. Türkben, C.; Uylaşer, V.; İncedayı, B.; Çelikkol, I. Effects of different maturity periods and processes on nutritional components of rose hip (Rosa canina L.). J. Food Agric. Environ. 2010, 8, 26-30.

7. Hallmann, E. The influence of organic and conventional cultivation systems on the nutritional value and content of bioactive compounds in selected tomato types. J. Sci. Food Agric. 2012, 92, 2840-2848. [CrossRef] [PubMed]

8. Ponder, A.; Hallmann, E. The nutritional value and vitamin C content of different raspberry cultivars from organic and conventional production. J. Food Compos. Anal. 2020, 87, 1-7. [CrossRef]

9. Fassett, R.G.; Coombes, J.S. Astaxanthin: A Potential Therapeutic Agent in Cardiovascular Disease. Mar. Drugs 2011, 9, 447. [CrossRef] [PubMed]

10. Méndez, D.H.; Mosquera, M. Carotenoid Pigments in Rosa mosqueta Hips, an Alternative Carotenoid Source for Foods. Agric. Food Chem. 2000, 48, 825-828. [CrossRef] [PubMed]

11. Andersson, S.C.; Rumpunen, K.; Johansson, E.; Olsson, M.E. Carotenoid content and composition in rose hips (Rosa spp.) during ripening, determination of suitable maturity marker and implications for health promoting food products. Food Chem. 2011, 689-696. [CrossRef]

12. Khoo, H.E.; Prasad, K.N.; Kong, K.W.; Jiang, Y.; Ismail, A. Carotenoids and Their Isomers: Color Pigments in Fruits and Vegetables. Molecules 2017, 16, 1710. [CrossRef]

13. Böhm, V.; Fröhlich, K.; Bitsch, R. Rosehip_A "new" source of lycopene? Mol. Asp. Med. 2003, 24, 385-389. [CrossRef]

14. Boileau, T.M.; Boileau, A.; Erdman, J.W. Bioavailability of all-trans and cis-Isomersof Lycopene. Exp. Biol. Med. 2002, 227, 914-919. [CrossRef] [PubMed]

15. Schieber, A.; Carle, R. Occurrence of carotenoid cis-isomers in food: Technological, analytical, and nutritional implications. Trends Food Sci. Technol. 2005, 16, 416-422. [CrossRef]

16. Najda, A.; Buczkowska, H. Morphological and chemical characteristics of fruits of selected Rosa sp. Mod. Phytomorphol. 2013, 3, 99-103. [CrossRef]

17. Demir, N.; Yildiz, O.; Alpaslan, M.; Hayaloglu, A.A. Evaluation of volatiles, phenolic compounds and antioxidant activities of rose hip (Rosa L.) fruits in Turkey. LWT-Food Sci. Technol. 2014, 57, 126-133. [CrossRef]

18. Howard, L.R.; Clark, R.J.R.; Brownmiller, C. Antioxidant capacity and phenolic content in blueberries as affected by genotype and growing season. J. Sci. Food Agric. 2003, 83, 1238-1247. [CrossRef]

19. Adamczak, A.; Buchvald, W.; Zielinski, J.; Mielcarek, S. Flavonoid and Organic Acid Content in Rose Hips (Rosa L., Sect. Caninae Dc. Em. Christ.). Acta Biol. Crac. Ser. Bot. 2012, 54, 105-112. [CrossRef]

20. Petkovsek, M.M.; Slatnar, A.; Stampar, F.; Veberic, R. The influence of organic/integrated production on the content of phenolic compounds in apple leaves and fruits in four different varieties over a 2-year period. J. Sci. Food Agric. 2010, 90, $2366-2378$. [CrossRef]

21. Nađpal, J.D.; Lesjak, M.M.; Šibul, F.S.; Anačkov, G.T.; Četojević-Simin, D.D.; Mimica-Dukić, N.M.; Beara, I.N. Comparative study of biological activities and phytochemical composition of two rose hips and their preserves: Rosa canina L. and Rosa arvensis Huds. Food Chem. 2016, 192, 907-914. [CrossRef] [PubMed] 
22. Elmastaş, M.; Demir, A.; Genç, N.; Dölek, Ü.; Güneş, M. Changes in flavonoid and phenolic acid contents in some Rosa species during ripening. Food Chem. 2017, 235, 154-159. [CrossRef]

23. Bhave, A.; Schulzova, V.; Chmelarova, H.; Mrnka, L.; Hajslova, J. Assessment of rosehips based on the content of their biologically active compounds. J. Food Drug Anal. 2017, 25, 681-690. [CrossRef]

24. Skrypnik, S.; Chupakhina, G.; Feduraev, P.; Nataliia, C.; Maslennikov, P. Evaluation of the rose hips of Rosa canina L. and Rosa rugosa Thunb. as a valuable source of biological active compounds and antioxidants on the Baltic Sea coast. Pol. J. Nat. Sci. 2019, 34, 395-413.

25. Stănilă, A.; Diaconeasa, Z.; Roman, I.; Sima, N.; Maniutiu, D.; Roman, A.; Sima, R. Extraction and Characterization of Phenolic Compounds from Rose Hip (Rosa canina L.) Using Liquid Chromatography Coupled with Electrospray Ionization-Mass Spectrometry. Not. Bot. Horti Agrobot. 2015, 43, 349-354. [CrossRef]

26. Chambial, S.; Dwivedi, S.; Shukla, K.K.; John, P.J.; Sharma, P. Vitamin C in Disease Prevention and Cure: An Overview. Indian J. Clin. Biochem. 2013, 28, 314-328. [CrossRef]

27. Wilson, J. The physiological role of dehydroascorbic acid. FEBS Lett. 2002, 527, 5-9. [CrossRef]

28. Lee, S.K.; Kader, A.A. Preharvest and postharvest factors influencing vitamin C content of horticultural crops. Postharvest Biol. Tecnol. 2000, 20, 207-220. [CrossRef]

29. Al-Yafeai, A.; Bellstedt, P.; Böhm, V. Bioactive Compounds and Antioxidant Capacity of Rosa rugosa Depending on Degree of Ripeness. Antioxidants 2018, 7, 134. [CrossRef] [PubMed]

30. Uggla, M.; Gao, X.; Werlemark, G. Variation Among and Within Dogrose Taxa (Rosa sect. caninae) in Fruit Weight, Percentages of Fruit Flesh and Dry Matter, and Vitamin C Content. Acta Agric. Scand. B 2003, 53, 147-155. [CrossRef]

31. Kaack, K.; Kuhn, B.F. Evaluation of rose hip species for processing of jam, jelly and soup. Tidsskr. Planteavl. 1991, 95, 353-358. [CrossRef]

32. Nojavan, S.; Khalilian, F.; Kiaie, F.M.K.; Rahimi, A.; Arabanian, A.; Chalavi, S. Extraction and quantitative determination of ascorbic acid during different maturity stages of Rosa canina L. fruit. J. Food Compos. Anal. 2008, 21, 300-305. [CrossRef]

33. Ercişli, S.; Eşitken, A. Fruit characteristics of native rose hip (Rosa spp.) selections from the Erzurum province of Turkey. N. Z. J. Crop. Hortic. Sci. 2004, 32, 51-53. [CrossRef]

34. Wright, K.P.; Kader., K.P. Effect of slicing and controlled-atmosphere storage on the ascorbate content and quality of strawberries and persimmons. Postharvest Biol. Technol. 1997, 10, 39-48. [CrossRef] 